How to cite: Hansmann, R. 2019. Specialised airport infrastructure to support connectivity: The case of Dube

Tradeport, eThekwini Municipality, South Africa. Town and Regional planning, no.74, pp. 36-50.

\section{Specialised airport infrastructure to support connectivity: The case of Dube Tradeport, eThekwini Municipality, South Africa}

\section{Robynne Hansmann}

DOI: http://dx.doi.org/10.18820/2415-0495/trp74i1.4

Revised April 2019, Published 30 June 2019

*The author declared no conflict of interest for this title or article

\begin{abstract}
South Africa's policy framework is firmly committed to an infrastructure-led development path in order to support inclusive and widespread growth. The implementation of largescale transportation infrastructure spent on ports, road, rail and airports is positioned to support multi-scaled growth through trade in sub-Saharan Africa. Convergence of policy and practice-based research findings make a strong case for increasing international trade in, and within sub-Saharan Africa, through improved international connectivity, regional integration and logistics as a strategy for shifting the growth potential of the region. The development of Dube TradePort (DTP), including King Shaka International Airport (KSIA), was based on the rationale that airports support trade and the movement of goods between global and regional economies, through improved logistics at the local level. This article interrogates the assumption that long-term investment in airport infrastructure and related industrial uses are sufficient preconditions to support trade with the expanding sub-Saharan markets. A case study approach, including interviews, observations, and document reviews, was used to better understand aircargo development at DTP in eThekwini Municipality. Previous studies on DTP have investigated how space is shaped in the vicinity of the airport through governance and ownership arrangements. This study focuses on how a purpose-built airport with precincts, containing specialised infrastructure and related uses, interacts with the flow of goods as distinct from passenger flows. Findings suggest that, while DTP plays a role in attracting foreign and local investment and related trade, structural trade dynamics are impacting on African connectivity in the movement of goods between global and regional economies.
\end{abstract}

Keywords: Air cargo, airport infrastructure, Greenfields, logistics

\section{GESPESIALISEERDE LUGHAWE-INFRASTRUKTUUR OM KONNEKSIE TE ONDERSTEUN: DUBE TRADEPORT GEVALLESTUDIE, ETHEKWINI- MUNISIPALITEIT, SUID-AFRIKA}

Die Suid-Afrikaanse beleidsraamwerk is stewig verbind tot 'n infrastruktuur-geleide ontwikkelingspad om inklusiewe en wydverspreide groei te ondersteun. Die implementering van grootskaalse vervoerinfrastruktuurbesteding op hawens, paaie, treine en lughawens is geposisioneer om multi-skaalgroei te ondersteun deur handel in Afrika suid van die Sahara. Konvergensie van beleids- en praktykgebaseerde navorsingsbevindings maak'n sterk saak vir die toenemende internasionale handel in en binne Afrika suid van die Sahara deur verbeterde internasionale konnektiwiteit, streeksintegrasie en logistiek as 'n strategie vir die verskuiwing van groeipotensiaal van die streek. Die ontwikkeling van Dube TradePort (DTP), insluitende die King Shaka Internasionale Lughawe (KSIA), was gebaseer op die rasionaal dat lughawehandel en die beweging van goedere tussen globale en streeksekonomieë deur verbeterde logistiek op die plaaslike skaal ondersteun word. Hierdie artikel ondersoek die aanname dat langtermynbelegging in lughaweinfrastruktuur en verwante nywerheidsgebruike voldoende voorwaardes is om handel met groeiende markte suid van die Sahara te ondersteun. 'n Gevallestudiebenadering, insluitende onderhoude, waarnemings, en dokumentresensies is onderneem om lugvragontwikkeling by DTP in die eThekwini Munisipaliteit beter te verstaan. Vorige studies oor DTP het gekyk na hoe ruimte in die omgewing van die lughawe gevorm word deur bestuursen eienaarskapsreëlings. Hierdie studie fokus op hoe 'n doelgebaseerde lughawe met gebiede wat gespesialiseerde infrastruktuur en verwante gebruike bevat, in wisselwerking met die vloei van goedere verskil van passasierstrome. Bevindings dui daarop dat, terwyl DTP 'n rol speel in die aantrek van buitelandse en plaaslike beleggings en verwante handel, het strukturele handelsdinamika 'n impak op Afrika-konnektiwiteit in die beweging van goedere tussen globale en streeksekonomieë.

Sleutelwoorde: Groenvelde, logistiek, lughawe-infrastruktuur, lugvrag

\section{MERALO YA MOTHEO E IKGETHILENG YA BOEMAFOFANE HO TSHEHETSA DIKGOKAHANO: TABA YA DUBE TRADEPORT, ETHEKWINI MUNICIPALITY, SOUTH AFRICA}

Molawana wa moralo wa Afrika Borwa o inehetsekabotlalohotselayantshetsopele e etelletsweng pele ke meralo ya motheo bakeng sa ho tshehetsa kgolo e nang le kenyelletso le e phatlalletseng. Ketsahatso ya sekala se seholo sa meralo ya motheo ya transporoto e sebedisitsweng boemakepeng, tseleng, diporong le boemafofaneng, e beilwe ho tshehetsa kgolo ya "multi-scaled" ka kgwebisano ka hare ho sub-Saharan Africa. Kopano ya molawana le diphumano tsa dipatlisiso tse itshetlehileng hodima ketsahatso, di etsa taba e tsitsitseng bakeng sa ho eketsa kgwebisano ya matjhabatjhaba mona le ka hare ho sub-Saharan Africa, le ka dikgokahano tse ntlafaditsweng tsa matjhabatjhaba, le kopano ya lebatowa le thophiso tse hlokahalang ho etsa hore tshebetso e atlehe (logistics), jwalo ka leano bakeng sa ho tjhetjhisa kgonahalo ya kgolo ya lebatowa. Ntshetsopele ya Dube TradePort (DTP), ho kenyelletswa King Shaka International Airport (KSIA),

Ms Robynne (R.) Hansmann, Lecturer, Department of Town and Regional Planning, Durban University of Technology, PO Box 1334, Durban, 4000, South Africa. Phone: 0313732666, e-mail: <robynne@dut.ac.za> DOI: https://orcid.org/0000-0002-6251-2357

SSB/TRP/MDM 2019 (74):36-50 ｜ＩSSN 1012-280 ｜ e-ISSN 2415-0495 
di ne di itshetlehile hodima motheo wa hore maemafofane a tshehetsa kgwebo wa lefatshe lohle le wa lebatowa, ka dithophiso tse ntlafaditsweng tse hlokahalang ho etsa hore tshebetso e atlehe (improved logistics) boemong ba selehae.

Atikele ena e botsollotsa monahano wa hore letsete/peheletso ya tjhelete ya nako e telele meralong ya motheo ya boemafofane le ditshebediso tse amanang le indasteri, ke ditlhoko tse lekaneng bakeng sa ho tshehetsa kgwebo le dimmaraka ka hare ho subSaharan Africa. Mokgwa wa thuto ya mehlala, ho kenyelletswa le diinthaviu, ditemoho, le tekolobotjha ya ditaba tse ngotsweng, di sebedisitswe ho utlwisisa hantle ntshetsopele ya air-cargo ho DTP eThekwini Municipality. Dithuto tse fetileng ho DTP di entse diphuputso tsa hore na sebaka se bopilwe jwang sebakeng sa boemafofane ka ditlhophiso tsa tsamaiso ya puso le monga sona. Thuto ena e tsepamisitse maikutlo hodima boemafofane bo ahilweng ka lebaka la dipehelo tse nang le meralo e kgethehileng ya motheo le mabaka a amehang; di kopana le ho falliswa ha thepa jwalo ka ha di fapane le ho falliswa ha batho. Diphumano di hlahisa hore, le ha DTP e bapala karolo bakeng sa ho hohela letsete/peheletso ya tjhelete e tswang kantle le ya selehae, mmoho le kgwebo e amehang; ho fetoha ha sebopeho kgwebong ho le tsamao ya thepa dipakeng tsa moruo

na le tshwaetso kgokahanong ya Afrika bakeng sa ho tsamaisa thepa mahareng a lefatshe ka bophara le lebatoweng.

\section{INTRODUCTION AND RESEARCH PROBLEM}

Airports have attracted substantial critiques from planners relating to privatisation of spaces (Freestone, 2011), abetting sprawl (O'Connor, 2003), problematic land-use interfaces (Stevens \& Baker, 2013), and reduced environmental amenity (Charles, Barnes, Ryan \& Clayton, 2007). Considering the strategic spatial planning decisions at Dube TradePort (DTP) and King Shaka International Airport (KSIA), this article focuses on DTP's stated intention to improve foreign and local investment through airport-related infrastructure. The performance of trade emanating from the local investment is considered in terms of contradictory dynamics impacting on connectivity in Africa.

Air transportation plays an integral part in production and distribution networks supporting the movement of goods between global and local
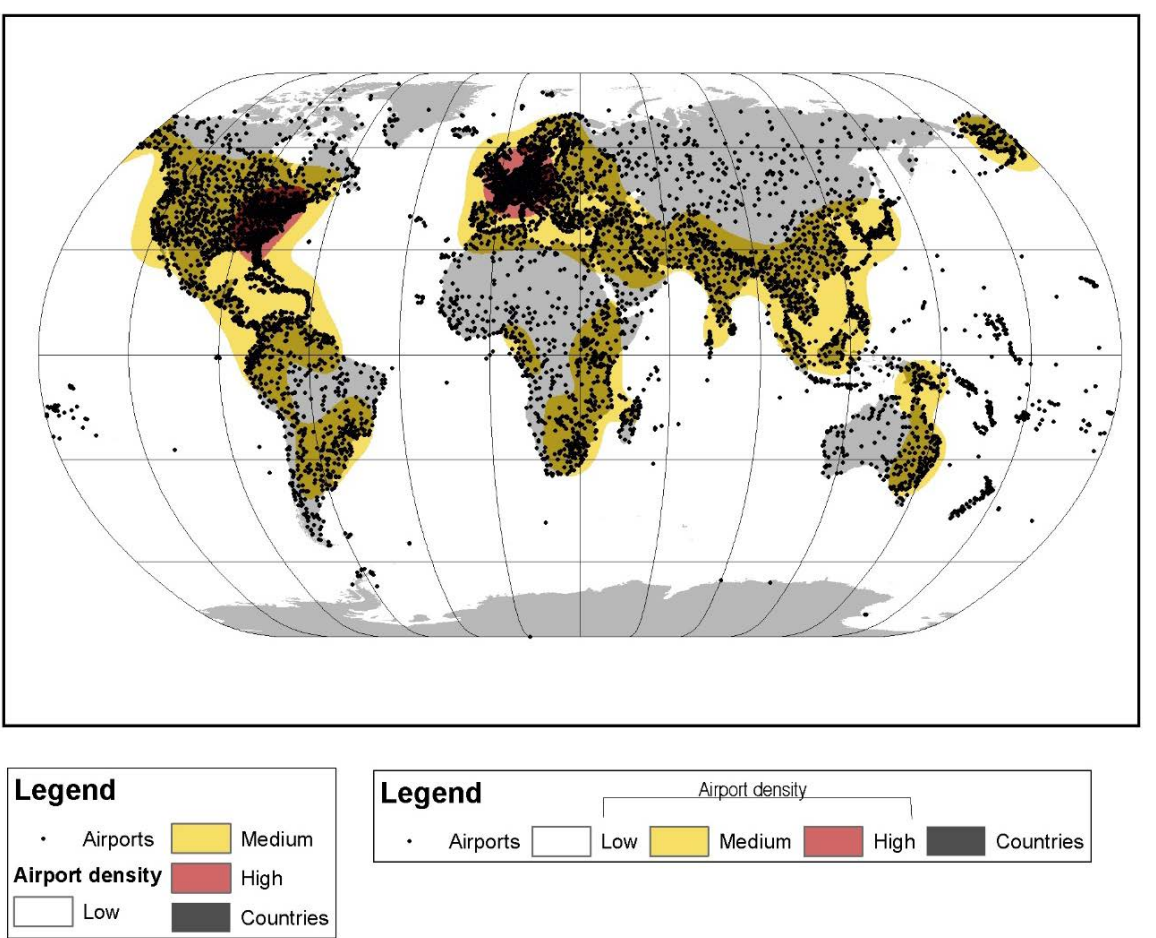

Figure 1: Geographical concentration of airports

Source: $\quad$ DUT Department of Town and Regional Planning, GIS Unit economies. While ports play a

dominant role in the amount of goods moving between international and local trade, airports are significant in the value of these high-value, perishable and time-sensitive goods. Air cargo accounts for less than $1 \%$ of the world trade tonnage and $35 \%$ of the world trade value, and over half of air cargo is moved internationally in dedicated freighters as opposed to wide-belly passenger planes (Boeing, 2017: 6). Although international trade is, to a large extent, sea-based and a small volume is moved by air, the landside modal choices between air, road and rail to distribute within the agreed price, time and quality parameters fall within the field of logistics and supply chain management. On the landside, the geography of distributing freight combined with dispersed production across cities creates city-wide land-use challenges for managing logistics-related growth.

Geographically, airfreight demand is highly concentrated, with approximately $85 \%$ of scheduled freighter flights operating from 50 cargo airports across North America, Asia, and Europe (Boeing, 2017: 6). Within Africa, air trade functions across a sparse network and air cargo accounts for some $8 \%$ of the total 1.8 billion tons of air cargo originating or destined for Africa. African air cargo is dominated by a few leading economies, with South Africa (16.1\%), Egypt (15.9\%), Kenya (12.9\%), Nigeria (10.7\%), Ethiopia (10\%) and others (34.3\%) accounting for respective shares in international air-cargo flows in 2015 (Boeing, 2017: 36). Bilateral and free trade agreements in Africa are encouraging new intra-Africa aircargo lanes. However, restrictions, protectionism (Meichsner, O'Connell \& Warnock-Smith, 2018:182), the cost and availability of current ground infrastructure (Button, Brugnoli, Martini \& Scotti, 2015: 85), and specialised air-cargo infrastructure limit the expansion of air services (Boeing, 2017: 36; Abate, 2016: 328).

Locally, air cargo is highly concentrated at the OR Tambo 
International Airport (ORTIA), where this hub accounts for approximately 399781 tonnes $(79 \%)$ of the national share of 504022 tonnes (ACSA, 2018). DTP, incorporating $\mathrm{KSIA}$, is specifically designed to support air-cargo logistics and is developing trade flows directly with Durban, moving outside the hub. Within eThekwini Municipality, KSIA and DTP are located some $40 \mathrm{~km}$ north of Africa's busiest container port, serving sub-Saharan Africa. The proximity raises some interesting issues on how infrastructure investments can add value to the existing trade-related flows through Durban and, in the long run, play a role in Southern African Development Community (SADC) regional integration. It is estimated that, within the SADC region, approximately $62 \%$ of exports come from South Africa (Hartzenberg, 2011: 11) and these are distributed on predominantly road-based networks. Infrastructure is identified as a constraint to trade in Africa, with extensive distances and transportation costs constraining landside distribution networks (Hartzenberg, 2011: 3-4; Meichsner et al., 2018: 182; New Partnership for Africa's Development (NEPAD), 2016: xii). These constraints reduce productivity gains, increase inventory stocks, and limit the development of new supply chains in Africa.

Imperatives for intra-African trade are well documented. However, the role of infrastructure-led development and specifically airport-led development, in achieving inclusive economic growth with poverty reduction outcomes, is unclear. Planning critiques of airportled development tend to focus on sustainability consequences of large-scale infrastructure. Yet hardly any attention is paid to questioning the underlying development path based on supply-side infrastructure investment to support trade and related economic growth. Air cargo moving through airports and the relationship with other modalities and land uses provide a useful entry point to probe the air-cargo logistics dynamics through purpose-built air infrastructure case, in order to assess trade and investment potential.

\section{CONCEPTUAL FRAMEWORK AND DEFINITIONS}

The significance of airfreight logistics invokes a body of literature on transport geography that investigates how tradable goods move in supply chains. Airports play a role in particular supply chains and, although the relative tonnage moving by air as opposed to sea is marginal, the demand for component parts and completed goods delivered on time across space drives the demand for air logistics. The prominence of air logistics differs between supply chains, but also varies at points in logistics processes related to production, distribution, consumption, or re-use of goods, dependent on how critical time is. Modal competition between air, road, rail and sea comes into play where highvalue goods are dependent on timing, but not urgent. There is substantial planning literature on airport-led development that explains the socioeconomic dynamics surrounding airports and the production of urban development in support aviation- and non-aviation-related land uses (Freestone \& Baker, 2011; Mokhele, 2017; Charles et al., 2007; Stevens \& Baker, 2013; Stevens, Baker \& Freestone, 2010) and on the cargo side-related air logistics (O'Connor, 2010; Coetzee \& Swanepoel, 2017; Boloukian \& Siegmann, 2016; O'Connor, 2013). The sequencing of broader property development investment decisions in the case study and the importance of the port relative to the airport in attracting logistics activity are part of a broader study not covered in this article. Conceptually, the article focuses on understanding how air cargo relates to production and distribution activity.

In this study, logistics refers to "the wide set of activities dedicated to the transformation and circulation of goods, such as the material supply of production, the core distribution and transport function, wholesale and retail and also the provision of households with consumer goods as well as the related information flows" (Hesse \& Rodrigue, 2004: 172). The definition implies two major interrelated functions of logistics. The first relates to the physical distribution function, with the derived transport segment, and the second relates to the materials management function with the induced transport segment (Hesse \& Rodrigue, 2004: 172). Physical distribution is the "movement of goods from the point of production to the point of consumption and materials management includes all the activities related in the manufacturing of commodities in all their stages of production along a supply chain" (Hesse \& Rodrigue, 2004: 173). Inherent in this spatially constructed notion of logistics is the idea of pursuing optimal integration between modalities as one layer, and the integration between places of production, distribution and consumption as another. The framework allows for a relational understanding of how infrastructure, designed to interact with the flow of goods across networks, holds possibilities, and how these flows can integrate with broader land-use processes. Air transportation forms part of the networks and nodes in the physical distribution and the materials management function and would need to integrate with other modes of transportation and production, storage and distribution use in order to fulfil this logistic function. The complexities lie in achieving connectivity within the air network as well as integration with land-based networks, where transportation networks underlie the territorial organisation of economic activities in space (Rodrigue, Comtois \& Slack, 2013: 22). In other words, interrogating air cargo within this definition of logistics focuses the research on both the distribution functions from production to consumption (including linkages with other modalities) interacting with air cargo and, secondly, the linkages with production land uses interacting with air cargo across supply chains. 
The extent to which networks are embedded in local employment, land use and supply chains is a factor in determining local equity gains.

Air transport is arguably not only a functional enabler, but also an outcome of logistics related to changes in global production processes. Logistics is critiqued in "mobities" literature for its role in perpetuating late capitalism and, by extension, related injustices and exclusions (Lin, 2018: 14). Birtchnell, Savitzky and Urry (2015: 6) raise concerns relating to global material circulation with critiques concerning development paths engaged with globalisation.

\section{LITERATURE REVIEW}

Airport-led development attracts both international and local attention through the convergence of practicebased and academic interest in the posited economic growth potential of airports. Proponents of positive economic development impacts argue that airports act as catalysts for urban growth in the era of globalisation (Addie, 2014: 87). By extension, these arguments for airport infrastructure expansion rely on the growth potential of the airport regions, where branding regions such as an Aerotropolis (Kasarda \& Lindsay, 2012; Kasarda, Appold \& Peoples Jr, 2014), and related spatial descriptions of airport-led development is evident (Freestone \& Baker, 2011). However, amidst the growth claims, airport regions are not without sustainability critiques related to fuels, noise (Charles et al., 2007; Kivits, Charles \& Ryan, 2010), cost overruns (Flyvbjerg, 2007; Robbins, 2015), contested political decisions (Todes, 2014), terrorism targets (Graham, 2006), and related to global pandemics (Hwang, Mahoney, James, Lin, Berro, Keybl, Goedecke, Mathieu \& Wilson, 2012).

The literature on whether airport activity is a function or cause of economic activity echoes deeper debates within transportation literature, questioning the merits of state infrastructure investments based on assumed growth relationships (Banister \& Berechman, 2000: 12). The debates on whether transport infrastructure investments engender economic development reflect assumptions on economic potential growth paths. The neoclassic growth theories that emphasise supply-side factors such as capital (investments and savings) and technology to promote economic growth have been favoured by endogenous growth theories that pick up on the importance of technology and infrastructure in the growth process. Button \& Taylor (2000: 214) note the prevalence of endogenous theories in airport-related research, with arguments for infrastructure investment to foster economic growth. These arguments are again evident in the African policy review, linking productivity growth to infrastructure provision as a publicsector activity that stimulates regional development. However, endogenous models are critiqued for insufficient attention paid to demands side issues such as exports and balance of payment constraints impacting on employment and productivity (Pike, Pose \& Tomaney, 2006: 107). The oversight of the historical socioeconomic and institutional contexts shaping the economic growth process has subsequently received more attention in regional planning.

The review found that econometric studies are a common empirical method for relating air-transport investment to national economic growth (Hakim \& Merkert, 2016; Allroggen \& Malina, 2014; Küçükönal \& Sedefoğlu, 2017; Baker, Merkert \& Kamruzzaman, 2015; Abate, 2016; Chang \& Chang, 2009; Button \& Yuan, 2013). However, the findings suggested conflicting results with respect to causality directions. Brueckner (2003: 1), corroborated by Green (2007: 111), both argue that airports may be a function, as well as a cause, of economic growth. However, in general, passenger activity as opposed to cargo activity is a better predictor of economic growth. In support of Brueckner (2003: 1), Sheard (2014: 146) also found that air infrastructure yields positive effects on service-sector employment, but no measurable effect on manufacturing or most of the non-tradable sectors, regardless of airport size in the USA. The direct, indirect and multiplier links between airports and economic development depend on the split between passenger- and cargofocused operations as well as on connectivity (Green, 2007; Kasarda \& Green, 2005; Brueckner, 2003). It is not surprising that studies indicate that national growth generates airport passenger demand (Allroggen \& Malina, 2014, Küçükönal \& Sedefoğlu, 2017), and in the context of significant growth in South East Asia, this generates both passenger and freight activity (Hakim \& Merkert, 2016). On the whole, findings linking economic growth and the demand for freight are ambiguous.

Research on Greenfields airports in Africa is restricted to the role of public-private partnerships (PPP) in infrastructure development, citing only three Greenfields airports in Africa since 2007 (Tomová, 2009: 13). Funding of Greenfields airports, even in the context of substantial airport privatisation over the past thirty years (Cruz \& Marques, 2011), is a challenge. Capital-intensive airport investments are particularly risky, given the scale of investment required, the sensitivity to economic climate, and the competition for routes. Not only is cost recovery difficult (Button, Costa \& Cruz, 2007:213), and cost overruns typical (Flyvbjerg, Holm \& Buhl, 2002: 4), but in PPPs the state assumes substantial commercial risk (Cruz \& Marques, 2011: 394). The concessions for private spending are typically applied over thirty-year periods (Cruz \& Marques, 2011: 394).

The assertion that transportation infrastructure relates to economic growth is a widely held view justifying substantial state investment in infrastructure expansion plans. However, given the association between growth and broader economic performance, the context 
of the airport-related investment matters. This review suggests a more nuanced and contextdependent approach relating airport development to connectivity, which may offer useful insights into the regional dynamics of freight and urban development. Globally, air-cargo flows are more strongly localised than air-passenger flows, reflecting traditional concentrations of global production output (Bowden, 2014). The distinction between the differential logics behind the geography of passenger and air cargo flows is important to understand the implied air connectivity. Airports can arguably leverage agglomeration gains in cities and improve accessibility to markets. However, established economies are shown to induce greater passenger growth, with related gains. In the case of freight activity, the airport infrastructure is not a sufficient precondition for growth; the local and regional context is key in the production and distribution of goods in specific supply chains related to airports.

\section{POLICY REVIEW}

Practice-based literature recognises that, although Africa holds a relatively marginal share in aviation services, the potential for growth is significant. According to the International Air Transport Association (IATA), air freight grew more than twice as fast as global trade volumes during 2017 , with the most significant margins emerging post-global financial crisis of 2010 (International Air Transport Association, 2018b: 12). Strong growth internationally was attributed in part to the global inventory restocking cycle, as well as to the demand for manufactured exports (IATA, 2018a: 8).

However, notable growth in Africa, with related changing air-trade patterns, is attributed to trade and investment opportunities from increased participation in global markets, population growth and increased foreign investment from Asia (International Air Transport Association, 2018a: 4). Currently, the intra-regional African share of airfreight is $12.9 \%$ of African trade, with some $60 \%$ trade with Europe. However, this intraregional share has grown by more than $35 \%$ over the past two years, reflecting a significant change in patterns of African trade (Boeing, 2017: 36).

Assumptions that trade causes growth are implicit in the World Bank's policy agendas to promote open trade. In the context of sub-Saharan intraregional trade, Button et al. (2015: 88) claim that the World Bank, rather than fund equipment and air infrastructure, have reoriented their trade creation policy towards regulatory support functions. According to the World Bank investigations, the African markets are highly fragmented and, while some countries have removed import duties within regional blocks, obstacles such as non-tariff and regulatory barriers limit the movement of goods across borders and raise the transactional costs (World Bank, 2012: xvii). The implied agenda is to promote regional trade and to strengthen the internal integration within Africa. The impact is that Africa is more integrated with the rest of the world than itself, specifically through air connectivity.

The discourse on liberalisation and free trade as mechanisms to open African markets to export and investments remains contested. Promotion of free trade is evident in the policy agendas of international lending agencies (IMF and the World Bank) and reflected in the dominant research agenda on air services in Africa. Research on airport-led development in Africa, particularly at the national level, is based, to a large extent, on econometric models forecasting future demand. It argues that greater liberalisation in air trade promotes growth (Njoh, 2008; Button et al., 2015; Njoya, 2016; Adler, Njoya \& Volta, 2018; Ssamula, 2012; Ssamula \& Venter, 2013; Abate, 2016). Njoya (2016: 1) assessed some of the impediments to liberalisation of African air services and found that Southern African countries are particularly reluctant to enter into agreements to open up the competition and, by implication, place subsequent pressure on costs. Njoya (2016: 1) argues for the creation of a single African aviation market through the implementation of the Yamoussoukro Decision, aimed at airline cooperation and integration through liberalisation. However, a generic liberalisation strategy in pursuit of trade and growth is arguably questionable. Regionally appropriate and contextually derived development paths may hold the possibility for local and regional development (Pike, RodríguezPose \& Tomaney, 2007: 1255). In other words, variations in local and regional dynamics prompt differential responses to increased air connectivity and how connectivity is tied into place-based production.

Trade liberalisation is suggestive of a wider neoliberal agenda to enhance economic competitiveness. It is also arguably one of the neoliberal policy packages whereby freemarket principles are privileged over state protectionism to ensure adherence to laissez-faire multilateral free trade. The main concern is that neoliberal policies tend to restrict public intervention in the market, potentially constraining the planning instruments. As a public interest activity based on normative principles of inclusive growth, planning can be at odds with regional and national economic growth juxtaposed local environmental intrusion (Freestone, 2011: 129).

The thread of infrastructure-led development to strengthen intraAfrican trade and integration is consistently found in policy documents. Africa's Agenda 2063 anticipates the development of a "world-class integrative infrastructure" (AUC, 2015: 4-5). This focus echoes Goal 9 of the Sustainable Development Goals (SDG) adopted by the United Nations and calls for building "resilient infrastructure, promote sustainable industrialization and foster innovation" (UN, 2018: online). The African Union Commission's $(A \cup C)$ vision and strategy also 
include infrastructure provision in support of trade and inclusive growth (AUC, 2015: 5; 2013: 3). As the development agency for the AUC, the New Partnership for Africa's Development (NEPAD) focuses on regional integration, infrastructure, and trade. The NEPAD programmes to 'Move Africa' and the 'Programme for Infrastructural Development in Africa' (PIDA) implement the AUC's vision to promote development and poverty reduction through improved access to integrated regional and continental infrastructure networks and services. The argument for regional integration by the African Development Bank Group funding these programmes is to add value to African products, create larger markets, attract investment and trade for sustained and inclusive growth and development, and improve Africa's competitiveness (African Development Bank Group, 2015: 15). It is noted that coastal cities are critical for transit and that both airports and seaports feature as Africa's logistics and infrastructure hubs (African Development Bank Group, 2015: 24).

Industrialisation is at the centre of Africa's structural transformation, with infrastructure identified as the catalyst for NEPAD implementation (NEPAD, 2016: 8). Transportation costs in Africa are relatively high and raise concern for trade competitiveness. It is estimated that freight costs, as a percentage of import value, are $13 \%$ for Africa, compared to $8.8 \%$ for other developing countries, and $5.2 \%$ for industrial countries (NEPAD, 2016: xii). The importance of transport infrastructure, power and ICT are identified as contributors to economic development and poverty reduction in Africa. Within this context, aviation receives particular attention. NEPAD identified the creation of a single African Aviation Market as a flagship project, including renewed commitments to the liberalisation of air trade in Africa (NEPAD, 2017). Commitment to regional integration and sustained growth through the SADC member states is demonstrated in SADC
2015 Consolidated Treaty on matters related to infrastructure and trade (SADC, 2015: 2).

Within South Africa, there is again a strong policy alignment from national, provincial to local, supporting an infrastructure-led growth path. The National Development Plan (NDP) argues the case for greater integration in the global economy to engage with new opportunities based on a leap in trade that promotes sustainable and inclusive growth by 2030 (South Africa. National Planning Commission, 2012: 49). Transport infrastructure features in the National Vision for "supporting the movement of goods from points of production to where they are consumed, facilitating regional and international trade" (South Africa. National Planning Commission, 2012: 166). The NDP spatially targets the development of the Durban-Gauteng freight corridor in terms of the role of moving the country's high-value freight (South Africa. National Planning Commission, 2012: 166). The National Medium Term Strategic Framework 2014-2019 in support of

\section{SPATIAL DEVELOPMENT FRAMEWORK 2018-2019}

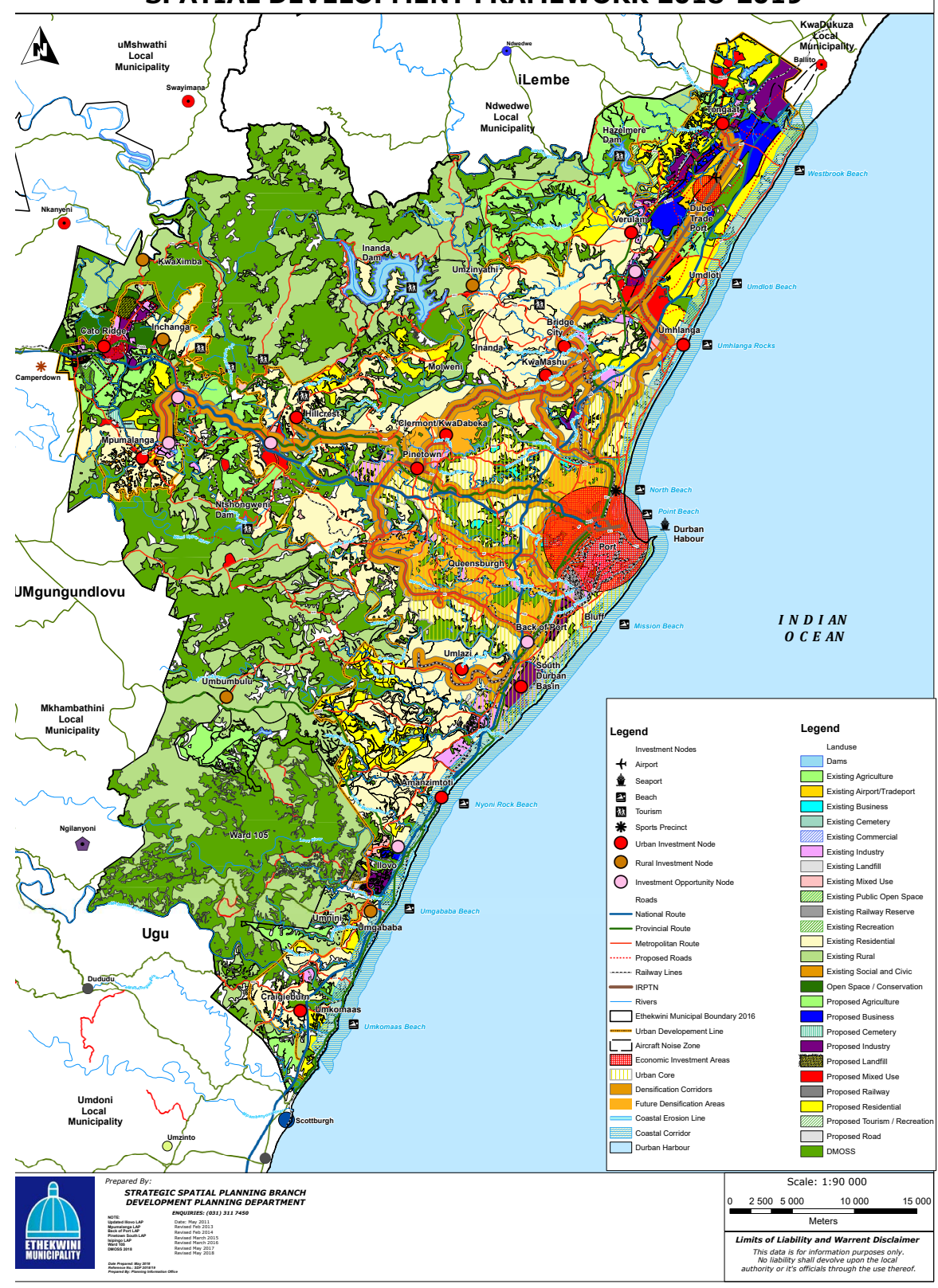

Figure 2: eThekwini Municipal Spatial Development Framework Source: $\quad$ South Africa. eThekwini Municipality, 2018: 719 
the NDP reiterates the development of efficient competitive and responsive economic infrastructure, supported by Strategic Integrated Projects (SIPS) (South Africa. The Presidency, 2017: 23-24). The Durban-Gauteng corridor or SIP2 corridor aligns with the NDP to ensure that infrastructure is adequately planned and coordinated to promote the efficient movement of goods (South Africa. Presidential Infrastructure Coordinating Commission, 2012). At a provincial level, DTP and the emerging 'Aerotropolis' play a central role in KwaZulu-Natal's (KZN) Provincial Growth and Development Plan, 2011-2030 (South Africa. Province of Kwa-Zulu-Natal, 2011: 118). Locally, DTP features in the Integrated Development Plan (IDP), despite earlier political contestations with the municipality (Todes, 2014: 264), and the subsequent inclusion in the IDP. Although the strong policy alignment is evident, the coordination, sequencing and funding of infrastructure locally is a challenge. Key impacts emanating from freight movements in the Spatial Development Framework include the sub-optimal split of moving goods by road instead of rail from ports; associated GHG emissions of freight travel and challenges of growing exports within an economic slowdown and downgraded investment climate (South Africa. eThekwini Municipality, 2018: 130).

\section{DUBE TRADEPORT CASE STUDY}

The DTP development site is the largest infrastructural project in the $\mathrm{KZN}$ province and forms part of the NDP for the country. The site is strategically located in relation to infrastructure supporting trade and is some $35 \mathrm{~km}$ north of the container port of Durban and some $150 \mathrm{~km}$ south of the bulk port of Richard's Bay on the main provincial north-south N2 corridor. As part of the strategic infrastructure project (SIP) for the Durban-Free State Gauteng Logistics and Industrial Corridor, DTP is $40 \mathrm{~km}$ north of the western N1 corridor connecting the Durban container port with Johannesburg. The established road-based freight corridor is strongly tied to Africa's busiest port and the nature of sea freight varies substantially in volume and value to air freight. Arguably, access to both sea and air infrastructure provides flexibility in how goods move.

DTP falls within the KZN province, on the eastern seaboard of South Africa, and is home to some 10.3 million people (STATSSA, 2011). The study area is located within the metropolitan area of eThekwini Municipality, where some 3.44 million people live, $30.2 \%$ are unemployed, and the growth rate is estimated at $1.08 \%$ between 2001 and 2011(STATSSA, 2011).

The adjacent municipality of Ndwedwe (within the llembe District Municipality) has a population of 140820 people, with unemployment at $48.7 \%$ and a $-0.2 \%$ growth rate between 2001 and 2011 (STATSSA, 2011). North of DTP, between the eThekwini border and the south of the Tugela River, is KwaDukuza Municipality (within the llembe District Municipality), with a population of 231187 , unemployment at $25 \%$ and growth at $2.3 \%$ between 2001 and 2011 (STATSSA, 2011). The growth dynamics of KwaDukuza and eThekwini on the northern corridor are arguably interrelated.
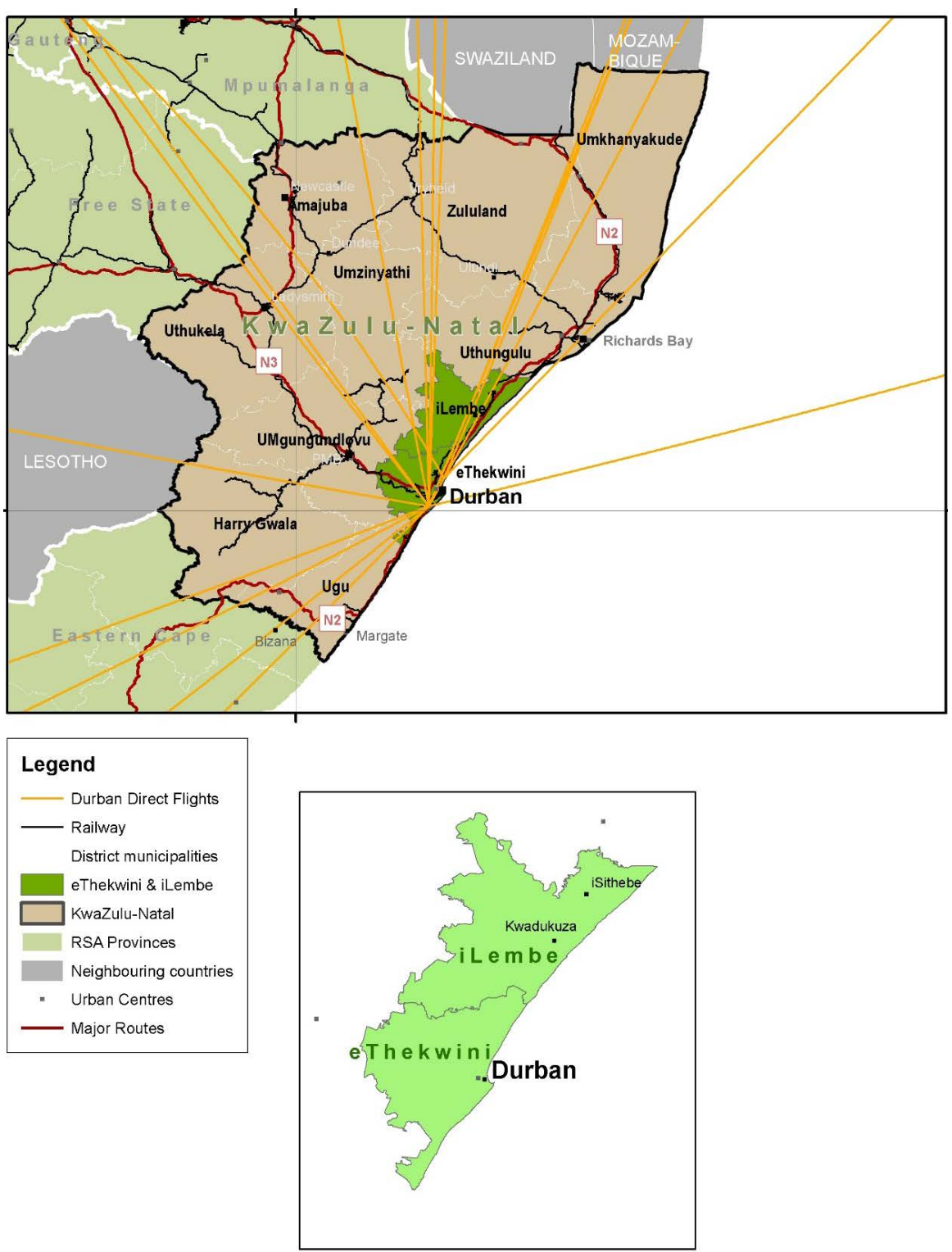

Figure 3: Location of Dube TradePort within KwaZulu-Natal

Source: DUT Department of Town and Regional Planning, GIS Unit 
In the study on suburbanisation processes, Todes (2014: 245$)$ found that these areas displayed differential forms of growth related to land ownership. The dynamics of a dominant landowner, Tongaat Hulett, on the northern corridor surrounding the airport, was found to shape development in contrast to fragmented patterns displayed in KwaDukuza. Imperatives for DTP to create employment and contribute towards regional growth, particularly as a state entity tasked with promoting investment in $\mathrm{KZN}$, are high (DTP, 2018: 12). According to DTP, public and private capital expenditure into Dube TradeZone 1 and Dube AgriZone 1 created 46367 employment opportunities in $\mathrm{KZN}$ to date, including construction and operations, and contributed approximately $\mathrm{R} 9.5$ billion into the national GDP (DTC, 2017c:10). According to Robbins (2015: 3), the estimated construction costs covered by the state and related entities were in the order of R8 billion rand (USD1 billion in 2010), with employment, cargo volumes and passenger numbers below the estimates on opening. The limitations of reaching short-term conclusions on the case of DTP, after some three years in operation, are recognized, given that airports plan for 10- and 30-year horizons.

DTPC was established to implement the development of the international airport and logistics platform to the north of eThekwini Municipality, Durban. The specific mandate for DTPC has shifted over the development phases of the project, initially conceived as a TriPort, multimodal logistics platform to a 'global manufacturing and air logistics platform' responsible for development of the DTP site, including the designated Special Economic Zone (SEZ) to promote foreign and local investment (DTC, 2017a: 4; South Africa. eThekwini Municipality, 2015: 143). The designation of DTPC in 2016 as SEZ operator broadened the vision to enhance manufacturing and export capacity, and to attract foreign direct investment through government incentives and investor-related infrastructure. The specific SEZ incentives include $15 \%$ corporate tax for qualifying entities, $10 \%$ per annum building allowance, employment incentives for low-income workers, import duty rebates for export-related production, value-added tax exemption under specific conditions for South African procedures, supplies and tax incentives (DTC, 2017b:2). In fact, the DTP mandate is strongly aligned with the government's industrialisation policy to support trade by deriving agglomeration benefits of airport infrastructure as well as the spatially targeted investment through the SEZ instrument.

The DTP site includes KSIA, a dedicated cargo terminal, with a range of supporting precincts focused on warehousing, offices, retail, hotels, and agriculture. The site precinct shown in Figure 4 is divided into a number of precincts, with complex ownership arrangements related to the institutional arrangements negotiated between DTPC and ACSA in the lead-up to the site opening in 2010 , and more recently including Tongaat Hulett in TradeZone 3. The Cargo Terminal Precinct and TradeZone Precinct are owned by DTP and leased to tenants, while the Airport Precinct is owned by ACSA. ACSA owns and operates OR Tambo International Airport (ORTIA), Cape Town International Airport (CTIA), KSIA and the balance of regional airports in the country. DTPC is a provincial state-owned entity (SoE), and owns and operates Dube CargoTerminal, TradeZone, AgriZone and Dube City.

The 3 800-hectare site is centred on the Airport Precinct including KSIA passenger terminal with a $3.7 \mathrm{~km}$ runway. The Dube CargoTerminal located at mid-runway is a cargohandling facility, including cold storage, with direct, secure airside access. The TradeZone Precinct is designed for airport-related industrial activities with warehousing and logistics uses. Integral to the design is the TradeHouse, comprising of warehousing space and forwarders and shippers offices above. An elevated conveyor transfer system links the TradeHouse with the TradeZone to the adjacent Cargo Terminal. The AgriZone precinct comprises greenhouses, packing and sorting facilities, and related uses. Dube City Precinct is for business and hospitality purposes. The site was designed as a 60-year master plan underpinned with precinct plans approved by the municipality. Prior to the submission of site plans with the Municipality, an internal review system checks for consistency and the drawdown of development rights.

Prior to the construction, relocation and opening of the KSIA within DTP site on 1 May 2010, the previous Durban Airport operated as a regional airport, with limited runway length, some $20 \mathrm{~km}$ south of the Durban Port. The airport relocation was motivated first, by the stimulus to the regional economy through direct international long-haul flights; secondly, the growth in high-value manufactured and perishable goods, and, thirdly, investment opportunities created through connectivity (Institute of Natural Resources, 2006: 24).

The project became operational in the wake of the global economic crisis and despite the impact of the World Cup opening on the passenger side, the cargo side opened with limited air connectivity. Current passenger volumes of 5.6 million place KSIA as the third busiest airport in South Africa (DTC, 2018: 17). In their study on African networks, as a proxy for globalisation, Otiso, Derudder, Bassens, Devriendt \& Witlox (2011: 619) rank Durban fourth in Africa and note that, along with Johannesburg, Cairo, Cape Town, Nairobi, Casablanca, and Durban, is also relatively well integrated into the global urban airline network. Initially, the air-cargo volumes between May 2010 and March 2012 were averaged at 337 tons for imports and 105 tons for exports per month (DTC, 2012a: 37). However, after some eight years of operation, cargo volumes have increased by $138 \%$ to a total of 19 498 tons in 2017 (DTC, 2018: 14). DTP's share of air-handling has 


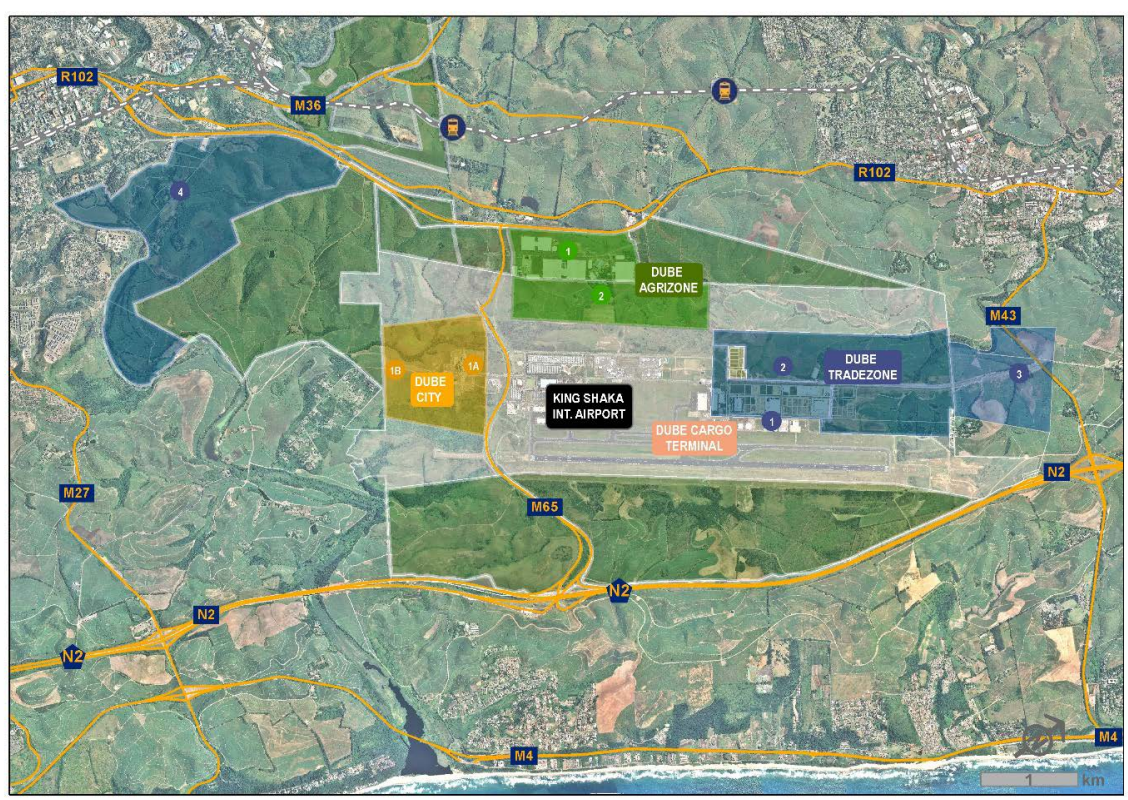

Figure 4: Location of Dube TradePort site, including the King Shaka International Airport and Dube CargoTerminal

Source: DUT Department of Town and Regional Planning, GIS Unit

shifted, despite low levels of domestic economic growth. Changes in air connectivity at KSIA have impacted on the supply side of air-cargo handling volumes, with four additional routes flying from 2015 (Qatar Airways, Turkish Airlines, Ethiopian Airlines and Proflight Zambia), although only three are related to the Cargo Terminal, and another three in 2016 (including Air Seychelles and Air Namibia). Although Ethiopian Airlines, Air Seychelles and SA Express withdrew in 2017, this was offset by the addition of Air Mauritius and more recently British Airways services in 2018. Air-cargo growth has exceeded the GDP growth for KZN, due partly to the opportunities created through increased connectivity with Durban and partly to modal competition for transporting specific goods (Bantwini, 27 August 2018: interview).

KSIA offers a range of scheduled and unscheduled flights and low-cost operations to short- and medium-haul destinations in the domestic market and growing regional market, as well as a small share of long-haul international flights. There are 19 direct destinations from Durban, of which 11 are international destinations. These connect to 118 second international destinations and a further 694 third-stop international destinations (DUT, 2017). DTP handles international cargo only and domestic operations are carried out by tenants in the Dube CargoTerminal. The international market is exclusively served through the existing wide-bodied aircraft, fixing the destination of exports through the related passenger hubs, rather than scheduled international freighter services. Charter freighters are arranged on an ad hoc basis, specifically where outsized cargo cannot be accommodated in the belly. Domestically, the air-cargo market is served by scheduled carriers, on a standard body B 737 (less than 45 tons). This aircraft has the capacity for approximately 7 tons, but on average carries about 4.5 tons a year, and the Cargo Terminal handles approximately $11 \%$ of the domestic cargo tonnage (Erskine \& Bantwini, 2017: interview). In 2017, domestic cargo was restricted by both the domestic economic climate and reduced cargo capacity on domestic routes (DTC, 2018: 40).

The Cargo terminal was purpose-built to support airfreight industry growth in $\mathrm{KZN}$, with sufficient capacity to support long-term development. The cargo handling has a capacity of
100000 tonnes of cargo annually, although current volumes are a fifth of the ultimate capacity (see Table 1).

The ability to move high-value to weight and time-critical goods, including component parts and perishable goods, was part of the initial strategy for developing an international air-cargo strategy for the $\mathrm{KZN}$ province. Although this requires dedicated and specialist air-cargo facilities, warehousing and an integrated network of intermodal logistics services, the bulk of air cargo is not transported in dedicated air freighters, as initially planned. In other words, in the context of DTP, domestic airfreight capacity is more strongly tied to production capacity, whereas international airfreight follows connectivity through passenger hubs.

Goods, either able to absorb the higher cost of transport into pricing or due to time demands, are handled by the CargoTerminal and include electrical components and electronics, closely followed by engines, machines, equipment, and, more recently, clothing. Opportunities to establish linkages to well-established manufacturing and automotive clusters in Durban are important in the context of local economic stagnation and high unemployment figures.

DTP have invested in the Dube Automotive Supply Park, located some 50 minutes to the south of the site. Mahindra have opted to locate a production plant in the TradeZone for opening in 2018.

The development of the SEZ at DTP has reinforced spatially targeted government industrialisation strategies, with the intention of developing specific clusters in the TradeZone adjacent to the CargoTerminal. The conversion of the previous Industrial Development Zone (IDZ) in 2014 to the SEZ can derive benefits for industrial development related to both proximity to transport infrastructure and fiscal incentives. The availability of serviced, zoned industrial land on the site saw the 26-hectare first phase developed, the balance sold out, and 

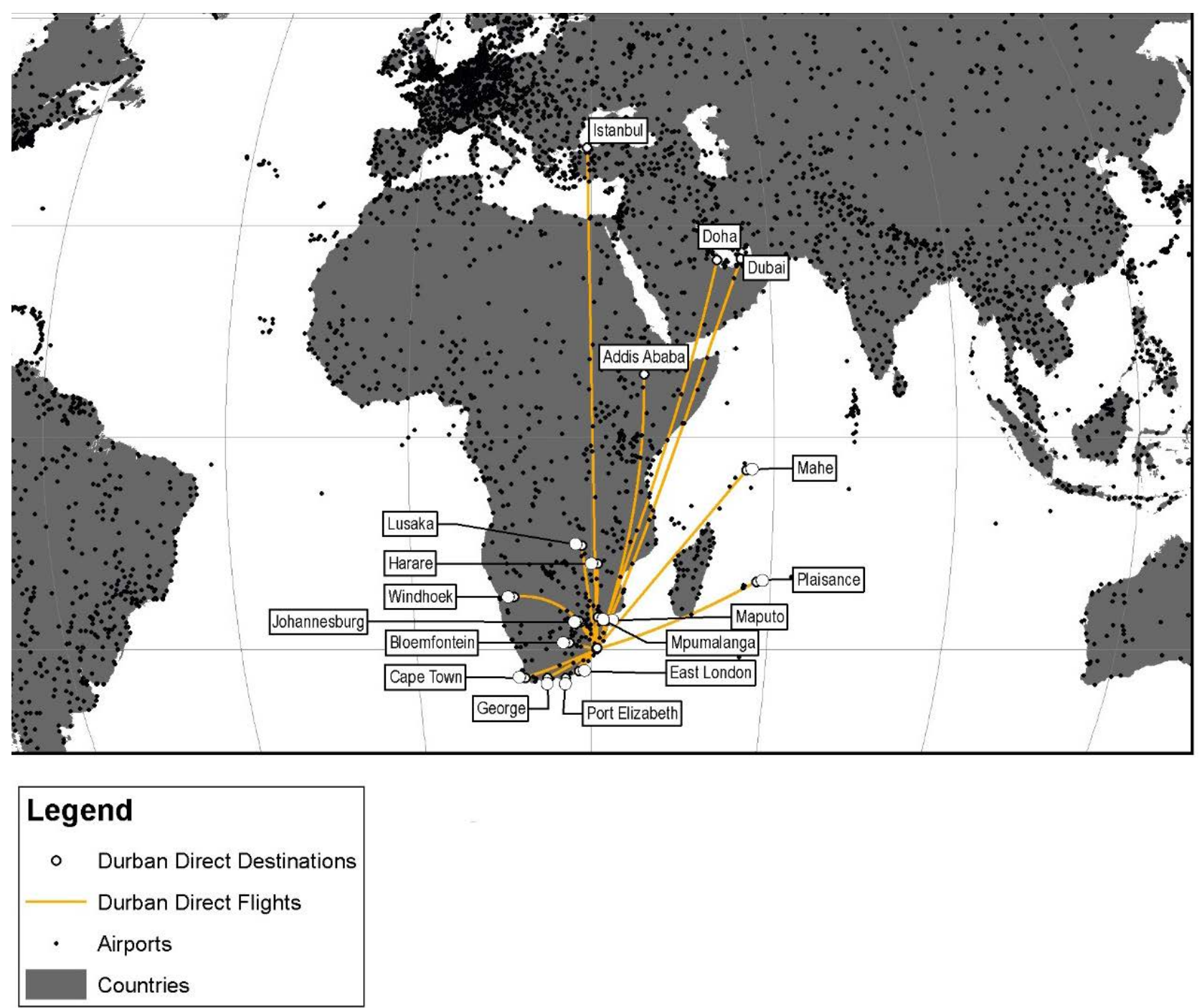

Figure 5: Durban direct destinations

Source: $\quad$ DUT Department of Town and Regional Planning, GIS Unit

the 43-hectare second phase due for release following planning approval (DTC, 2018). Enterprises requiring air connectivity are targeted in the SEZ. However, the first phase shows uneven air dependence. Further development of the SEZ is intended for manufacturing, assembling, air-related cargo distribution, hightech aerospace services, electronics, and pharmaceuticals production, automotive, clothing, textiles, cold storage, warehousing, distribution, and logistics (DTC, 2018:6). Within the TradeZone, including the SEZ, the total investment value, by either Black-owned or -empowered companies, is approximately R1.629 billion (DTC, 2018: 41).

On the investment side at the TradeZone, DTP have sold their first phase and are in the process of developing the second phase of manufacturing linked to the 'air logistics platform'. The SEZ at Dube TradeZone specifically targets investment towards electronics, pharmaceuticals and aerospace manufacturing, assembling and distribution firms. However, the real measure is not simply employment creation through on-site investment. Ensuring growth in air-freight volumes development through broader, regional supply chains is the measure in the longer term.

Although the development of the TradeZone derives some internal demand for airfreight, the pilot phase failed to secure strong airfreight linkages in all the sub-tenants. In subsequent development phases of TradeZone, requirements for air connectivity are implemented through targeted investment strategies, most notably in the automotive and pharmaceutical sectors. However, even on completion of the TradeZone, the viability of the Cargo Terminal is not based on internal demand. Some 20 freight-forwarding, logistics, storage and distribution companies are located in the facility to support air-related cargo distribution. Dube CargoTerminal also provides services directly to users of the facilities and it is estimated that some 380 role players in the logistics supply chain, including shippers, agents, air-cargo charter operators and logistics service providers, interact with the Cargo Terminal (Bantwini, 27 August 2018: interview). A minority of logistics operators at the airport and the bulk of logistics companies operating in Durban have 
Table 1: Performance of Dube Cargo Terminal 2010-2018

\begin{tabular}{|c|c|c|c|c|c|c|c|c|}
\hline & $2010^{i}$ & $2011^{i i}$ & $2012^{\mathrm{iii}}$ & $2013^{\text {iv }}$ & $2014^{v}$ & $2015^{v i}$ & $2016^{\text {vii }}$ & $2017^{\text {viii }}$ \\
\hline $\begin{array}{l}\text { Revenue from cargo handling } \\
\text { (imports and exports) }\end{array}$ & & & & & & $\begin{array}{l}\text { R9.4 } \\
\text { million }\end{array}$ & $\begin{array}{l}\mathrm{R} 10.2 \\
\text { million }\end{array}$ & $\begin{array}{l}\mathrm{R} 14,3 \\
\text { million }\end{array}$ \\
\hline $\begin{array}{l}\text { Tonnage through Dube Cargo } \\
\text { Terminal (international) }\end{array}$ & 5023 & 5060 & 6123 & 7681 & 7150 & 8062 & 10075 & 11351 \\
\hline $\begin{array}{l}\text { Tonnage through Dube Cargo } \\
\text { Terminal (domestic) }\end{array}$ & & & 3396 & 7335 & 6700 & 6427 & 7780 & 8147 \\
\hline $\begin{array}{l}\text { Value of goods through Dube } \\
\text { Cargo Terminal (international) }\end{array}$ & & & & $\begin{array}{l}\mathrm{R} 1.74 \\
\text { billion }\end{array}$ & $\begin{array}{l}\text { R4.3 } \\
\text { billion }\end{array}$ & $\begin{array}{l}\text { R4.8 } \\
\text { billion }\end{array}$ & $\begin{array}{c}\mathrm{R} 4.9 \\
\text { billion }\end{array}$ & $\begin{array}{c}\mathrm{R} 4.5 \\
\text { billion }\end{array}$ \\
\hline TOTAL TONNAGE & & & 9519 & 15016 & 13850 & 14489 & 17855 & 19498 \\
\hline
\end{tabular}

Notes:

DTC 2011.

DTC 2012b.ii

DTC 2013.iii

DTC 2014. iv

DTC 2015.

DTC 2016. ${ }^{\mathrm{vi}}$

DTC 2017b.vii

DTC 2018. ${ }^{\text {viii }}$

Source: Data from Dube TradePort Corporation Annual Reports 2010-2017

not relocated to the airport, due to the dominant role of the port and landside distribution on the N3 west (Wilkinson, 8 August 2018: interview).

\section{FINDINGS}

\subsection{Trade imbalances}

Air-cargo exports and, in particular, imports through Dube CargoTerminal have steadily grown since opening in 2010 , despite the relatively low volumes and off a low base. The growth reflects trade relations with specific countries. The majority of the shipments originate from, and go to Germany and China, closely followed by the USA. Markets between India and China are bi-directionally balanced with goods, which is not the case for total air cargo with Africa (Erskine \& Bantwini, 2017: interview). Bi-directionally balanced air-cargo routes are important for the Cargo Terminal, as it means that both import and export capacities are being utilised in a specialised infrastructure. In other words, it does not suffice to build up volumes annually by $12.7 \%$, as reflecting the trend over the past seven years (DTC, 2018: 12). It is specifically air-cargo exports that need to continue growing in order to promote local investment in the process. According to the DTP officials, exports are estimated at less than a quarter of international tonnage, but are increasing in proportion and volume annually (Bantwini, 27 August 2018: interview).

Hardly any air cargo moves to and from the Dube TradePort Cargo Terminal into Africa. This is mostly due to the imbalance of cargo movements and reflects the overall structure of trade. Future challenges for the Cargo Terminal will be to increase export air-cargo volumes in line with the SEZ strategy of developing air logistics and exportoriented manufacturing in order to promote local investment.

KZN exports significant amounts of freight to the SADC region, but imports hardly anything from the SADC region, making it very difficult for air-cargo operators to operate dedicated air-cargo flights to points within Africa. The KZN province exports significant amounts of freight to the SADC region, specifically Kenya and Angola. However, the relative imports from the SADC region are low. The imbalance of air-cargo movements creates challenges for backhaul opportunities and unsustainable point-to-point dedicated air-cargo operations. In fact, air cargo linked to passenger flows makes sense, until the volumes demand dedicated cargo operations within Africa.

In the absence of the local volumes supporting freighters, this secondary airport is tied to building air-cargo volumes through passenger connectivity and working more closely with hubs. Dube TradePort and its African route-development strategy should continue to link passenger air services with trade strategies in order to develop air-cargo volumes on the backhaul. Structurally, passenger and cargo connectivity cannot be viably delinked in the short term.

\subsection{Shift in volumes due to connectivity}

Although it was previously noted that air-cargo handling is concentrated at the ORTIA hub, the domestics and international volumes handled by DTP are increasing. The total air cargo handled between ORTIA, CTIA and KSIA is projected at 504022 tons in 2018 and recorded as 463 482 tons in 2017 , with a $9 \%$ growth (ACSA, 2018). ORTIA handled some 394430 tons relative to 19498 tons through Durban in 2017, with Durban accounting for a $4 \%$ share of total air cargo by weight (ACSA, 2018). However, in terms of domestic air cargo, it is estimated that the share is closer to 15\% (Bantwini, 27 August 2018: interview). Since opening, the DTP share of air-cargo handling has now shifted despite low levels of domestic economic growth. Air-cargo growth has exceeded the GDP growth for $\mathrm{KZN}$ and this is attributed partly to the opportunities created through increased connectivity with Durban and partly to modal 
competition for specific goods to move within a specified time.

\subsection{Shift in modality}

The strong hub-and-spoke arrangement for South African Airlines creates some challenges for a secondary city attempting to move outside this dynamic. International passengers from Durban have noted a significant growth in direct international flights specifically with Dubai, Doha, and Istanbul routings and, more recently, with British Airways. The development of pointto-point international connectivity on wide-body passenger aircraft is important for air cargo to avoid time and cost delays of routing through a hub, and also a main driver for increased volumes. However, these decisions are driven from a passenger viability perspective as opposed to cargo-routing logic.

On the demand side, shifts in the market share of goods handled by DTP are evident since opening. A portion of cargo previously moving by road has moved to air cargo, before landside distribution (Erskine \& Bantwini, 2017: interview). The relative share of air cargo from KZNbased companies, previously trucked to ORTIA, is reduced, and air cargo destined for KZN and previously trucked from ORTIA, has shifted in favour of DTP (Erskine \& Bantwini, 2017: interview). In other words, a portion of the export bound air cargo from KZN prefers ORTIA for exports, but the share is diminishing annually (Erskine \& Bantwini, 2017: interview).

It is estimated that Dube TradePort Cargo Terminal processes almost half of all air exports for the KZN province and three-quarter of all air imports, where previously the majority of the air cargo was being trucked between Durban and Johannesburg and flown out and in ORTIA (Erskine \& Bantwini, 2017: interview). By implication, this means that, in practice, DTP and ORTIA cooperate from a cargo-routing perspective, whereby DTP is favoured for imports directly destined for KZN and ORTIA will continue to hold a share of KZN-based exports, due to frequency and flexibility in routings. Given that the Dube TradePort Cargo Terminal is playing a greater role in terms of imports, this raises issues for managing landside logistics within the eThekwini Municipality.

\section{CONCLUSION}

Dube TradePort development has secured primacy in provincial investment spending and regional economic strategies. However, despite localised impacts, the project has managed to increase connectivity to international markets, build up local volumes (albeit in specific supply chains and relatively small), as well as attract local and foreign investment, all within in a relatively short time span.

The literature and policy review support the case for improved logistics and infrastructural integration to support trade, particularly where air connectivity embedded in local industrialisation builds regional trade volumes. Weak economic integration within Africa represents lost opportunities for developing larger trading markets and economies of scale associated with regional trading blocks. However, the mechanisms to support this regional trade lie beyond the physical infrastructure. Air connectivity, supported by trade agreements, has seen a shift in the African share of air cargo. Yet air connectivity between Africa and its trading regions is still stronger than trade within Africa. The finding points to dynamics beyond infrastructure design impacting on the forms of trade and investment at DTP.

DTP increased trade, but not in the way it was intended. African connectivity from Durban has emerged through new passenger services; yet route development is not accompanied by significant trade in Africa. One conclusion may be a tenuous link between liberalisation strategies and trade. However, the DTP case shows that air cargo is strongly tied to local production rather than passenger destinations.

The ultimate design of Dube CargoTerminal is based on the development of sub-Saharan supply chains related to connectivity, with sufficient import and export air-cargo volumes to support scheduled freighter services. However, the limited airfreight volumes from Africa for exports moving through DTP place the viability of dedicated freighters in the balance. Despite the sub-Saharan reach of the air-cargo infrastructure, the current trade imbalance works against building up trade volumes on the return flight. Strategies to align passenger and air-cargo connectivity through belly hold cargo are short-term strategies to offset risks of unbalanced backhaul. Longer term strategies relate to increased trade volumes.

\section{ACKNOWLEDGEMENTS}

The research was made possible through the National Research Grant 99324. Joe Kitching of Durban University of Technology assisted with the production of GIS maps.

\section{REFERENCES}

ABATE, M. 2016. Economic effects of air transport market liberalization in Africa. Transportation Research Part A: Policy and Practice, 92, pp. 326-337. https://doi.org/10.1016/j. tra.2016.06.014

ADDIE, J.-P.D. 2014. Flying high (in the competitive sky): Conceptualizing the role of airports in global cityregions through "aero-regionalism". Geoforum, 55(1), pp. 87-99. https://doi. org/10.1016/j.geoforum.2014.05.006

ADLER, N., NJOYA, E.T. \& VOLTA, N. 2018. The multi-airline $p$-hub median problem applied to the African aviation market. Transportation Research Part A: Policy and Practice, 107, pp. 187-202. https://doi.org/10.1016/j. tra.2017.11.011

\section{AFRICAN DEVELOPMENT BANK} GROUP. 2015. Regional Integration: Policy and strategy (RIPoS) 2014-2023. [Online]. Available at: <https://www. afdb.org/en/topics-and-sectors/topics/ regional-integration/programme-forinfrastructure-development-in-africapida/> [Accessed: 10 June 2017]. 
AUC (AFRICAN UNION

COMMISSION). 2013. The AU

Commission Strategic Plan 2014-2017.

[Online]. Available at: <https://au.int/

en/auc/strategic-plan-2014-2017>

[Accessed: 10 June 2017].

AUC (AFRICAN UNION

COMMISSION). 2015. Agenda 2063:

First Ten-Year Implementation Plan

2014-2023. Addis Ababa: African Union

Commission.

ACSA (AIRPORTS COMPANY OF SOUTH AFRICA). 2018. Performance review - ACSA IR

ALLROGGEN, F. \& MALINA, R. 2014. Do the regional growth effects of air transport differ among airports? Journal of Air Transport Management, 37, pp. 1-4. https://doi.org/10.1016/j. jairtraman.2013.11.007

BAKER, D., MERKERT, R. \& KAMRUZZAMAN, M. 2015. Regional aviation and economic growth: Cointegration and causality analysis in Australia. Journal of Transport Geography, 43, pp. 140-150. https://doi. org/10.1016/j.jtrangeo.2015.02.001

BANISTER, D. \& BERECHMAN, Y. 2000. The economic development effects of transport investments. A paper prepared for presentation at the TRANS-TALK Workshop held in November, pp. 6-8.

BIRTCHNELL, T., SAVITZKY, S. \& URRY, J. 2015. Cargomobilities: Moving materials in a global age. New York: Routledge. https://doi. org/10.4324/9781315866673

BOEING. 2017. Boeing World Air Cargo Forecast 2016-2017.

BOLOUKIAN, R. \& SIEGMANN, J. 2016. Urban logistics; a key for the airport-centric sevelopment - A review on development approaches and the role of urban logistics in comprehensive airport-centric planning. Transportation Research Procedia, 12, pp. 800-811. https://doi.org/10.1016/j. trpro.2016.02.033

BOWDEN, J.T. 2014. The economic geography of air transport. In: Andrew R. Goetz, A.R. \& Budd, L. (Eds). The Geographies of Air Transport. Ashgate, Farnborough: pp. 41-60.

BRUECKNER, J.K. 2003. Airline traffic and urban economic development. Urban Studies, 40(8), pp. 1455-1469. https://doi. org/10.1080/0042098032000094388
BUTTON, K., BRUGNOLI, A., MARTINI, G. \& SCOTTI, D. 2015. Connecting African urban areas: Airline networks and intra-Sub-Saharan trade. Journal of Transport Geography, 42, pp. 84-89. https://doi.org/10.1016/j. jtrangeo.2014.11.007

BUTTON, K., COSTA, A. \& CRUZ, C. 2007. Ability to recover full costs through price discrimination in deregulated scheduled air transport markets. Transport Reviews, 27(2), pp. 213-230. https://doi. org/10.1080/01441640600951949

BUTTON, K. \& TAYLOR, S. 2000. International air transportation and economic development. Journal of Air Transport Management, 6(4), pp. 209-222. https://doi.org/10.1016/ S0969-6997(00)00015-6

BUTTON, K. \& YUAN, J. 2013. Airfreight transport and economic development: An examination of causality. Urban Studies, 50(2), pp. 329-340. https://doi. org/10.1177/0042098012446999

CHANG, Y.-H. \& CHANG, Y.-W. 2009. Air cargo expansion and economic growth: Finding the empirical link. Journal of Air Transport Management, 15(5), pp. 264-265. https://doi. org/10.1016/j.jairtraman.2008.09.016

CHARLES, M.B., BARNES, P., RYAN, N. \& CLAYTON, J. 2007. Airport futures: Towards a critique of the aerotropolis model. Futures, 39(9), pp. 1009-1028. https://doi. org/10.1016/j.futures.2007.03.017

COETZEE, P.J.V.V. \& SWANEPOEL, P.A. 2017. Spatial relationships and movement patterns of the air cargo industry in airport regions. Journal of Transport and Supply Chain Management, 11, pp.1-10. https://doi. org/10.4102/jtscm.v11i0.297

CRUZ, C.O. \& MARQUES, R.C. 2011. Contribution to the study of PPP arrangements in airport development, management and operation. Transport Policy, 18(2), pp. 392-400. https://doi. org/10.1016/j.tranpol.2010.12.001

DTC (DUBE TRADEPORT

CORPORATION). 2011. Dube

TradePort Annual Report 2010-2011.

DTC (DUBE TRADEPORT

CORPORATION). 2012a. DTPC

Macroeconomic Impact Assessment 2011-2012.
DTC (DUBE TRADEPORT

CORPORATION). 2012b. Dube

TradePort Annual Report 2011-2012.

DTC (DUBE TRADEPORT

CORPORATION). 2013. Dube

TradePort Annual Report 2012-2013.

DTC (DUBE TRADEPORT

CORPORATION). 2014. Dube

TradePort Annual Report 2013-2014.

DTC (DUBE TRADEPORT

CORPORATION). 2015. Dube

TradePort Annual Report 2014-2015.

DTC (DUBE TRADEPORT

CORPORATION). 2016. Dube

Tradeport Corporation Annual Report 2015/2016. [online]. Available at: <http://cargoterminal.dubetradeport. co.za/SiteFiles/111486/DTPC\%20 Annual\%20Report\%202015-16.pdf> [Accessed: 10 June 2017].

DTC (DUBE TRADEPORT CORPORATION). 2017a. Dube Tradeport - Home. [Online]. Available at: <http://dubetradeport.co.za/> [Accessed: 10 June 2017].

DTC (DUBE TRADEPORT CORPORATION). 2017b. Dube Tradeport Corporation Annual Report 2016-2017. [online]. Available at: $<$ http://cargoterminal.dubetradeport. co.za/SiteFiles/111486/DTPC\%20 Annual\%20Report\%202015-16.pdf> [Accessed: 10 June 2017].

DTC (DUBE TRADEPORT CORPORATION). 2017c. Special Economic Zone Investment Brochure.

DTC (DUBE TRADEPORT CORPORATION). 2018. Dube Tradeport Corporation Annual Report 2017-2018.

DUT (Durban Institute of Technology). 2017. GIS data compiled by DUT.

FLYVBJERG, B. 2007. Cost overruns and demand shortfalls in urban rail and other infrastructure. Transportation Planning and Technology, 30(1), pp. 9-30. https://doi. org/10.1080/03081060701207938

FLYVBJERG, B., HOLM, M.S. \& BUHL, S. 2002. Underestimating costs in public works projects: Error or lie? Journal of the American Planning Association, 68(3), pp. 279-295. https:// doi.org/10.1080/01944360208976273

FREESTONE, R. 2011. Managing neoliberal urban spaces: Commercial property development at Australian airports. Geographical Research, 
49(2), pp. 115-131. https://doi. org/10.1111/j.1745-5871.2010.00679.x

FREESTONE, R. \& BAKER, D. 2011. Spatial planning models of airport-driven urban development. Journal of Planning Literature, 26(3), pp. 263-279. https://doi. org/10.1177/0885412211401341

GRAHAM, S. 2006. Cities and the 'war on terror'. International Journal of Urban and Regional Research, 30(2), pp. 255-276. https://doi. org/10.1111/j.1468-2427.2006.00665.x

GREEN, R.K. 2007. Airports and economic development. Real Estate Economics, 35(1), pp. 91-112. https://doi. org/10.1111/j.1540-6229.2007.00183.x

HAKIM, M.M. \& MERKERT, R. 2016. The causal relationship between air transport and economic growth: Empirical evidence from South Asia. Journal of Transport Geography, 56, pp. 120-127. https://doi.org/10.1016/j. jtrangeo.2016.09.006

HARTZENBERG, T. 2011. Regional integration in Africa. Working Paper ERSD-2011-14 for World Trade Organization, Economic Research and Statistics Division, pp. 1-26. https://doi. org/10.2139/ssrn.1941742

HESSE, M. \& RODRIGUE, J.-P. 2004. The transport geography of logistics and freight distribution. Journal of Transport Geography, 12(3), pp. 171-184. https://doi.org/10.1016/j. jtrangeo.2003.12.004

HWANG, G.M., MAHONEY, P.J., JAMES, J.H., LIN, G.C., BERRO, A.D., KEYBL, M.A., GOEDECKE, D.M., MATHIEU, J.J. \& WILSON, T. 2012. A model-based tool to predict the propagation of infectious disease via airports. Travel Medicine and Infectious Disease, 10(1), pp. 32-42. https://doi. org/10.1016/j.tmaid.2011.12.003

INSTITUTE OF NATURAL RESOURCES. 2006. Social impact assessment of Dube TradePort, Scoping Report. Institute of Natural Resources.

IATA (INTERNATIONAL AIR TRANSPORT ASSOCIATION). 2018a. Forescasting Airfreight Demand 2018.

IATA (INTERNATIONAL AIR TRANSPORT ASSOCIATION). 2018b. IATA Annual Review 2018.
KASARDA, J.D., APPOLD, S.J. \& PEOPLES Jr, J.H. 2014. Planning a competitive aerotropolis. The Economics of International Airline Transport (Advances in Airline Economics, 4) Emerald Group Publishing Limited, 4, pp. 281-308. https://doi.org/10.1108/ S2212-1609_2014_0000004010

Kasarda, D. \& Green, D. 2005. Air cargo as an economic development engine: A note on opportunities and constraints. Journal of Air Transport Management, 11(6), pp. 459-462. https://doi.org/10.1016/j. jairtraman.2005.06.002

KASARDA, J.D. \& LINDSAY, G. 2012. Aerotropolis: The way we'll live next. London: Penguin.

KIVITS, R., CHARLES, M.B. \& RYAN, N. 2010. A post-carbon aviation future: Airports and the transition to a cleaner aviation sector. Futures, 42(3), pp. 199-211. https://doi.org/10.1016/j. futures.2009.11.005

KÜÇÜKÖNAL, H. \& SEDEFOĞLU, G. 2017. The causality analysis of air transport and socio-economics factors: The case of OECD countries. Transportation Research Procedia, 28, 16-26. https://doi.org/10.1016/j. trpro.2017.12.164

LIN, W.Q. 2018. Catering for flight: Rethinking aeromobility as logistics. Environment and Planning D-Society \& Space, 36(4), pp. 683-700. https://doi. org/10.1177/0263775817697977

MEICHSNER, N.A., O'CONNELL, J.F. \& WARNOCK-SMITH, D. 2018. The future for African air transport: Learning from Ethiopian Airlines. Journal of Transport Geography, 71, pp. 182-197. https://doi.org/10.1016/j. jtrangeo.2018.06.020

MOKHELE, M. 2017. Spatial economic evolution of the airport-centric developments of Cape Town and OR Tambo International Airports in South Africa. Stads -en Streekbeplanning, 70, pp. 26-36. https://doi. org/10.18820/2415-0495/trp70i1.3

NEPAD (NEW PARTNERSHIP FOR AFRICA'S DEVELOPMENT). 2017. The single African air transport market. African Union Commission, NEPAD.

NEPAD (NEW PARTNERSHIP FOR AFRICA'S DEVELOPMENT) 2016. 16 Infrastructure projects for African integration. United Nations Economic Commission for Africa.
$\mathrm{NJOH}$, A.J. 2008. Implications of Africa's transportation systems for development in the era of globalization. The Review of Black Political Economy, 35, pp. 147-162. https://doi. org/10.1007/s12114-008-9032-0

NJOYA, E.T. 2016. Africa's single aviation market: The progress so far. Journal of Transport Geography, 50, pp. 4-11. https://doi.org/10.1016/j. jtrangeo.2015.05.009

O'CONNOR, K. 2003. Global air travel: Toward concentration or dispersal? Journal of Transport Geography, 11, pp. 83-92. https://doi.org/10.1016/ S0966-6923(03)00002-4

O'CONNOR, K. 2010. Global city regions and the location of logistics activity. Journal of Transport Geography, 18, pp. 354-362. https://doi. org/10.1016/j.jtrangeo.2009.06.015

O'CONNOR, K. 2013. High-density approaches to accommodating logistics activity in cities: A case study of Singapore. Logistics: Perspectives, Approaches and Challenges. Nova Science Publishers, Inc.

OTISO, K.M., DERUDDER, B., BASSENS, D., DEVRIENDT, L. \& WITLOX, F. 2011. Airline connectivity as a measure of the globalization of African cities. Applied Geography, 31, pp. 609-620. https://doi.org/10.1016/j. apgeog.2010.12.002

PIKE, A., POSE, A.R. \& TOMANEY, J. 2006. Local and regional development. London: Routledge. https://doi. org/10.4324/9780203003060

PIKE, A., RODRÍGUEZ-POSE, A. \& TOMANEY, J. 2007. What kind of local and regional development and for whom? Regional Studies, 41(9), pp. 1253-1269. https://doi. org/10.1080/00343400701543355

ROBBINS, G. 2015. The Dube TradePort-King Shaka International Airport mega-project: Exploring impacts in the context of multi-scalar governance processes. Habitat International, 45, 196-204. https://doi. org/10.1016/j.habitatint.2014.05.006

RODRIGUE, J.-P., COMTOIS, C. \& SLACK, B. 2013. The geography of transport systems. London: Routledge. https://doi.org/10.4324/9780203371183

SHEARD, N. 2014. Airports and urban sectoral employment. Journal of Urban Economics, 80, pp. 133-152. https://doi. org/10.1016/j.jue.2014.01.002 


\section{SOUTH AFRICA. ETHEKWINI} MUNICIPALITY. 2015. eThekwini Municipality Integrated Development Plan Final Review 2015-2016.

\section{SOUTH AFRICA. ETHEKWINI} MUNICIPALITY. 2017. eThekwini Municipality Integrated Development Plan 5 Year Plan 2017/18 to 2021/22.

\section{SOUTH AFRICA. ETHEKWINI} MUNICIPALITY. 2018. Municipal Spatial Development Framework 2018-2019.

\section{SOUTH AFRICA. NATIONAL} PLANNING COMMISSION. 2012. National development plan. Pretoria: Government printer.

SOUTH AFRICA. PRESIDENTIAL INFRASTRUCTURE COORDINATING COMMISSION. 2012. A summary of national infrastructure development plan. Pretoria: Government printer.

SOUTH AFRICA. PROVINCE OF KWAZULU-NATAL. 2011. KwaZulu-Natal provincial growth and development plan, 2011-2030.

SOUTH AFRICA. THE PRESIDENCY. 2017. Medium-term strategic framework 2014-2019.

SADC (SOUTHERN AFRICAN DEVELOPMENT COMMUNITY). 2015. Consolidated text of the Treaty of the Southern African Development Community.

SSAMULA, B. 2012. Comparing air transport network operations in sparse networks in Africa. Research in Transportation Business \& Management, 4, pp. 22-28. https://doi. org/10.1016/j.rtbm.2012.06.002

SSAMULA, B. \& VENTER, C. 2013. Application of hub-and-spoke networks in sparse markets. The case of Africa. Journal of Transport Economics and Policy, 47(2), pp. 279-297.

\section{STATSSA (STATISTICS SOUTH} AFRICA). 2011. Local Municipality Statistics South Africa. [online]. Available at: <http://www.statssa. gov.za/?page_id=993\&id=ethekwinimunicipality> [Accessed:

31 October 2018].

STEVENS, N. \& BAKER, D. 2013. Land use conflict across the airport fence: Competing urban policy, planning and priority in Australia. Urban Policy and Research, 31(3), pp. 301-324. https:// doi.org/10.1080/08111146.2013.785943
STEVENS, N., BAKER, D. \& FREESTONE, R. 2010. Airports in their urban settings: Towards a conceptual model of interfaces in the Australian context. Journal of Transport Geography, 18(2), pp. 276-284. https:// doi.org/10.1016/j.jtrangeo.2009.05.007

TODES, A. 2014. New African suburbanisation? Exploring the growth of the northern corridor of eThekwini/ KwaDakuza. African Studies, 73(2), pp. 245-270. https://doi.org/10.1080/00 020184.2014 .925188

TOMOVÁ, A. 2010. PPP projects and airports: Experience and state in world regions. Paper delivered at the $8^{\text {th }}$ Conference on Applied Infrastructure Research, Berlin, 9-10 October, pp. 9-10.

UN (UNITED NATIONS). 2018. Sustainable development goals. [online]. Available at: <https://www. un.org/sustainabledevelopment/ sustainable-development-goals/> [Accessed: 10 June 2018].

WORLD BANK. 2012. De-fragmenting Africa: Deepening regional trade integration in goods and services. Washington, DC: The World Bank. 